\title{
The Main Curricular Characteristics of the Health Education Programs and Interventions from the Romanian Primary School Educational System
}

Diana-Crina Marin, Mușata Bocoș 


\title{
The Main Curricular Characteristics of the Health Education Programs and Interventions from the Romanian Primary School Educational System
}

\author{
Diana-Crina Marin ${ }^{a^{*}}$, Mușata Bocoș ${ }^{b}$ \\ ${ }^{a}$ Doctoral School "Education, Reflection, Development", Babes-Bolyai University Cluj-Napoca, 7 Sindicatelor Street, 400029, Romania \\ ${ }^{b}$ Babes-Bolyai University, Faculty of Psychology and Educational Sciences, Babes-Bolyai University Cluj-Napoca, 7 Sindicatelor Street, 400029, \\ Romania \\ *Corresponding author: Diana.PANCU@ubbonline.ubbcluj
}

\section{Abstract}

Keywords:

Health Promotion School,

Health Education Programmes, decision-making,

relevant topics of the activities
Within this study, we proposed to accomplish an analysis of the main health education programs implemented in our country during the last 20 years. In this regard, a series of health education programs and projects implemented at the primary school level of the educational units in our country were analyzed. We proposed to establish an inventory of the most frequently encountered topics of these programs, in addition to the identification of these programs, their initiators and their main partners. Thus, online searches were conducted in order to identify international, national, regional and local educational programs and projects. The main goal of these programs was the formation and development of health education related behaviors, knowledge, and attitudes. Moreover, a series of documents made by primary school teachers were analyzed, in order to conclude which are the main topics of these educationall partnership projects initiated in the scope of health education. The study highlights the importance of implementing such interventions, by identifying effective measures that can be taken in order to successfully organize and implement such programs.

\section{Zusammenfasung}

\section{Schlüsselworte:}

Gesundheitsförderungsschule, Gesundheitsbildungsprogramme, Entscheidungsfindung, relevante Themen für Aktivitäten
Im Rahmen dieser Studie schlugen wir vor, eine Analyse der wichtigsten Programme zur Gesundheitserziehung durchzuführen, die in unserem Land während der letzten 20 Jahre. In diesem Zusammenhang wurde eine Reihe von Programmen und Projekten zur Gesundheitserziehung in wurde das Grundschulniveau der Bildungseinheiten in unserem Land analysiert. Wir schlugen vor, eine Bestandsaufnahme der meisten häufig anzutreffende Themen dieser Programme, zusätzlich zur Identifizierung dieser Programme, ihrer Initiatoren und ihrer Hauptpartner. So wurden Online-Recherchen durchgeführt, um internationale, nationale, regionale und lokale Bildungsprogramme und -projekte zu identifizieren. Die wichtigsten Ziel dieser Programme war die Bildung und Entwicklung von Verhaltensweisen, Wissen und Einstellungen im Zusammenhang mit der Gesundheitserziehung. Darüber hinaus wurde eine Reihe von Dokumenten von Grundschullehrern analysiert, um festzustellen, welches die Hauptthemen dieser Bildungs-/Partnerschaftsprojekte sind, die im Rahmen von Gesundheitserziehung. Die Studie unterstreicht die Bedeutung der Umsetzung solcher Interventionen, indem sie wirksame Maßnahmen, die ergriffen werden können, um solche Programme erfolgreich zu organisieren und umzusetzen.

\section{Introduction}

The statistical data collected at the national level regarding the health status and the frequency of unhealthy behaviors of the population reveal the need to implement health education programs, consisting of health promotion activities. The right to health is a fundamental right of pupils. Effective health education programs undertook aim to maintain the physical, social and mental well-being of each pupil and parent involved in these programs. The strategic directions adopted by our country must pay special attention to the organization and implementation of preventive and educational programs for health education, which will contribute to maintaining the wellbeing of the population. Health education programs initiated and carried out at the school level have the role of consolidating knowledge and developing healthy life behaviors and skills.

\section{Theoretical foundation}

Schools are the ideal space for conducting health education programs, given the high number of participants 
who can be included simultaneously in these projects and the positive impact on students' health status of participating in this type of activity (Sherman \& Muehlhoff, 2007; Adamowitch, Gugglberger, Dür, 2017; Glanz, Rimer \& Lewis, 2002; Lister-Sharp, Chapman, Stewart-Brown, \& Sowden, 1993). It would be beneficial if, in the early stages of the development of health education programs, schools that enroll in the pattern of Health Promoting Schools (HPS), receive adequate support (Adamowitch, Gugglberger, Dür, 2017). The mode that the concept of "Health Promoting Schools" is understood and implemented has effects on both the behaviors adopted by the students and on the policies adopted at the organizational level (Lee, Lo, Keung, Kwong \& Wong, 2019; Lister-Sharp, Chapman, StewartBrown \& Sowden, 1993). The concept of "Health Promoting Schools" was introduced by the World Health Organization. The changes take place both in terms of content and organization of training activities, as well on the aspect of the school space, on the quality of interpersonal interactions and the well-being of all educational actors (Lister-Sharp, Chapman, StewartBrown, \& Sowden, 1993; Rowling, Jeffreys, 2006). Evaluating the effectiveness of health promotion (HPS) initiatives is a complex process, which should be based on predefined indicators (Inchley, Muldoon \& Currie, 2006; Lister-Sharp, Chapman, Stewart-Brown \& Sowden, 1993; Mukoma \& Filsher, 2004). Pupils adopt unhealthy daily behaviors, like allocating high time intervals to watch TV shows or play computer games (Dorman, 1997). Griebler, Rojatz, Simovska \& Forster, (2014) indicate that participation in school health promotion measures and decision-making process has multiple advantages from many perspectives such as high interest and involvement of the students who generate positive social relationships with teachers and other students and an increased level of competences and knowledge. The involvement of family and other community members ensures the efficiency of educational actions carried out in schools with the purpose to train and to develop healthy behaviors (Samdal \& Rowling, 2011; Lister-Sharp, Chapman, Stewart-Brown, \& Sowden, 1993). Also, the duration of educational programs implemented by schools is a factor that ensures the success of the activities carried out (Nutbeam, 1998).

The National Program "Health Education in the Romanian School" (https://gov.ro/fisiere/programe_fisiere/program-educatiesanatate.pdf) is the most important program implemented at the national level, in order to carry out teaching activities in the field of health education. The purpose of this program, launched in 2001, was the introduction of the activities of Health Education "in all educational units, as an optional discipline (full offer) and/ or as integrated hours in other subjects, as well as an extra-curricular activity, for training purposes of responsible attitudes among students towards their health and those around them". The main objectives of the program are: promoting the health and well-being of the students, personal development of the students and prevention. Health Education has become an optional discipline since 2004. The discipline is taught by biology teachers or by primary school teachers. In Romania, in the primary education cycle, the discipline "Health education" is an optional discipline, part of the curriculum at the school's decision. However, various contents specific to this discipline are reached through interdisciplinary connections, through the contents included in the school programs of other study disciplines, of which we mention the disciplines in the curricular area "Human and society". The inclusion of this study discipline in the Romanian school coincided with the recognition of the significant impact that the actions of health education realized in school contexts have on the student's health. Often, health education projects are organized at the initiative of non-governmental or governmental organizations, through the partnership agreements. Extracurricular activities are an effective way of achieving the objectives of the health education discipline.

From the analysis of some national and international legislative documents, emerges the need to develop prevention and health education programs. In the document "Health 2020. A European policy framework and strategy for the 21 st century" it is mentioned that "a broader multiagency strategy is required, to which people themselves can contribute. A broad range of stakeholders can be mobilized to support programs that promote health, including generational activities. For young people, these can include policies to improve the social and economic status of children living in disadvantaged circumstances; whole-school approaches to school-based activities to develop and protect children's social and emotional wellbeing, including school-based health literacy programs; peer-to-peer education; and the development of youth organizations. Integrating work on mental and sexual health into these programs and activities is particularly important". 
The "National Health Strategy 2014 - 2020, Health for Prosperity"

(http://www.old2.ms.gov.md/sites/default/files/cadrul_eur opean_de_politici_sanatate_2020.pdf) includes information on the need for the implementation of health education programs in pre-university education in our country. Thus, it is considered that it is necessary to carry out early information activities among the students on the topic of health education, with the purpose to prevent and combat risky behaviors and to contribute to the formation of a healthy lifestyle. For the implementation of the strategic directions set out in the National Health Strategy 2014 - 2020, Health for Prosperity, the Integrated Multiannual Health Promotion and Health Education Plan has been developed. This framework document was prepared by the Presidential Administration, UNICEF Romania, the Ministry of National Education, the Ministry of Health, the World Health Organization, the National Institute of Public Health, the National School of Public Health Management and Improvement in the Health Field. The Plan mentions the fact that the activities of health promotion and health education, can be carried out in schools or kindergartens, through close collaboration with doctors and nurses from the family medicine cabinets and school medical cabinets, units of secondary and tertiary care, community nurses, teachers, pharmacists, students of post-secondary medical schools, students of medical faculties, midwives, members of non-governmental organizations, social workers, volunteers from the community, etc. The authors of this document outline that although schools do not have a coherent program to ensure health education, they must provide the necessary framework for carrying out activities, adapted to their age and development needs.

\section{Research methodology}

During this research, the method of consulting documents prepared by various educational institutions in our country and published on the Internet was used. Within the study, we set out to answer questions such as:

1. What have been the themes of the activities included in the health education programs, who were implemented at the national level in the last 20 years in our country, at the initiative of the school units, of the Ministry of National Education or other governmental or nongovernmental organizations operating in our country?
2. What are the main educational partners of the educational school units, in the implementation of health education programs/projects?

3. What were the main themes of the educational projects carried out in the Romanian schools, starting from this theme?

\section{Results}

The National Program "Education for Health in the Romanian School" (https://gov.ro/fisiere/programe_fisiere/program-educatiesanatate.pdf) aims to achieve learning activities in formal, non-formal or informal contexts, starting from topics such as:

- Healthy alimentation;

- Emotional health;

- Personal hygiene;

- Physical activities and recreational activities. Healthy daily habits;

- The health of the environment;

- Accident prevention methods and first aid rules;

- Gender differences and family roles.

Also, among the large projects carried out by various NGOs in our country, there is the "Healthy Choices" program, initiated by the non-governmental organization "Save the Children Romania". The main topics of the activities were balanced nutrition, physical movement, emotional health, sexual education, prevention of the consumption behaviors of dangerous substances. Other projects identified by us addressed topics such as personal hygiene, healthy eating, and healthy life habits.

The website www.eTwinning.net has been consulted in order to determine if there are any projects on health education to which Romania was a partner. Thus, between 25 March and 30 March 2020, were searched specially designed projects for the age group of 6-11 years in the section "Health studies". The search returned 861 results. 115 projects (mostly in English) were selected. The selected projects were focused on developing awareness of the importance of health education, developing healthy behaviors or positive attitudes towards their own or others' health (see figure no. 1). Most of the projects to which 
educational institutions in our country were partners have addressed the issue of healthy eating (16 projects) and aspects related to maintaining a healthy lifestyle through physical exercises and adopting healthy behaviors (13 projects).

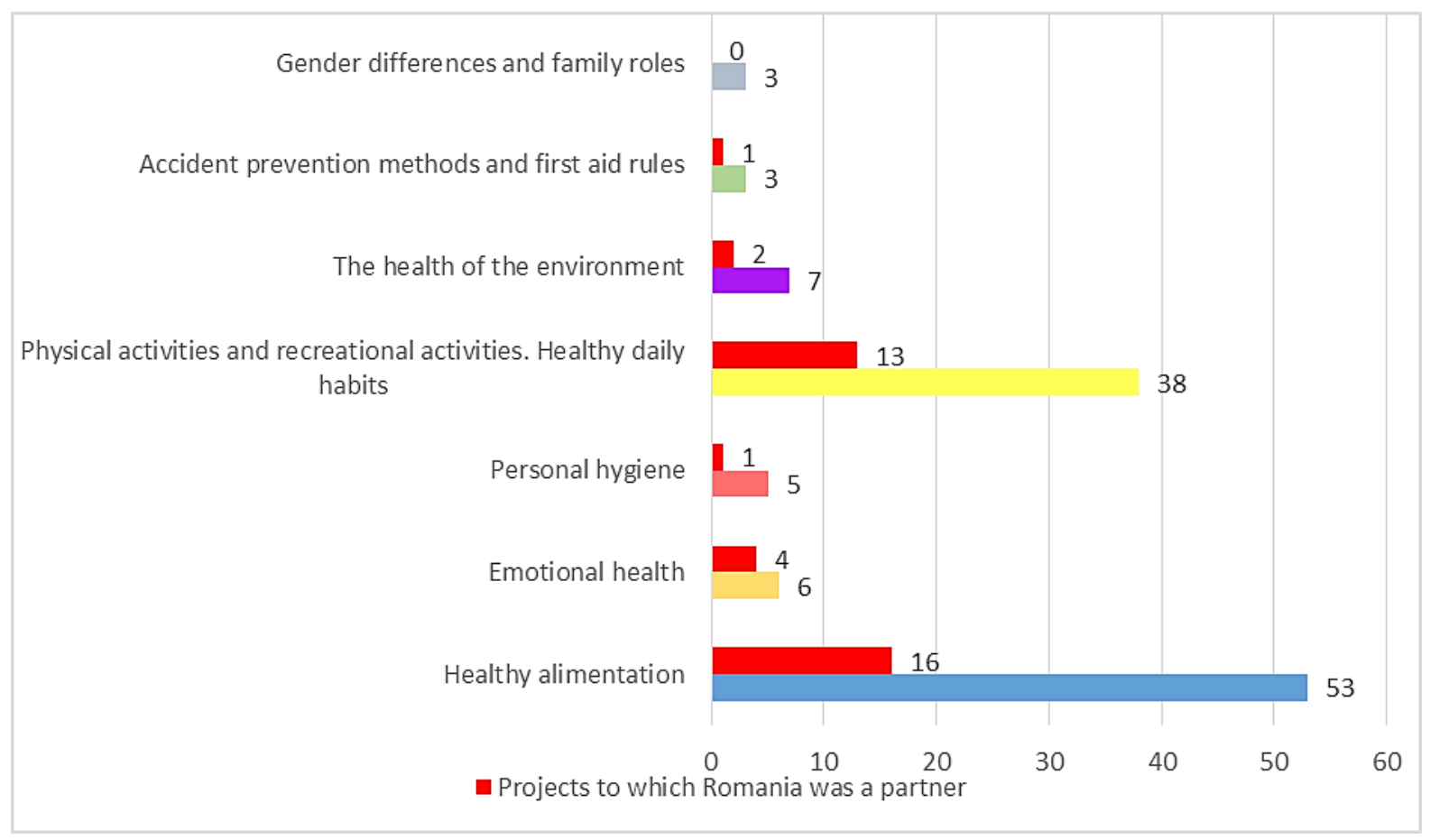

Figure 1. Topics of the projects identified on the eTwinning platform

The educational platform www.didactic.ro was used with the purpose to establish which are the main topics of the health education projects carried out in schools in our country. Thus, between 20 and 25 March, a series of school documents (including educational partnership projects) were analyzed, which consisted in the planning or presentation of educational activities carried out in the field of health education. To generate the results were used keywords such as: "health" (145 results), "healthy" (141 results), and "health education" (54 results). Most projects address topics such as balanced nutrition, the health of the environment, healthy habits of life and personal hygiene (see figure no. 2). 


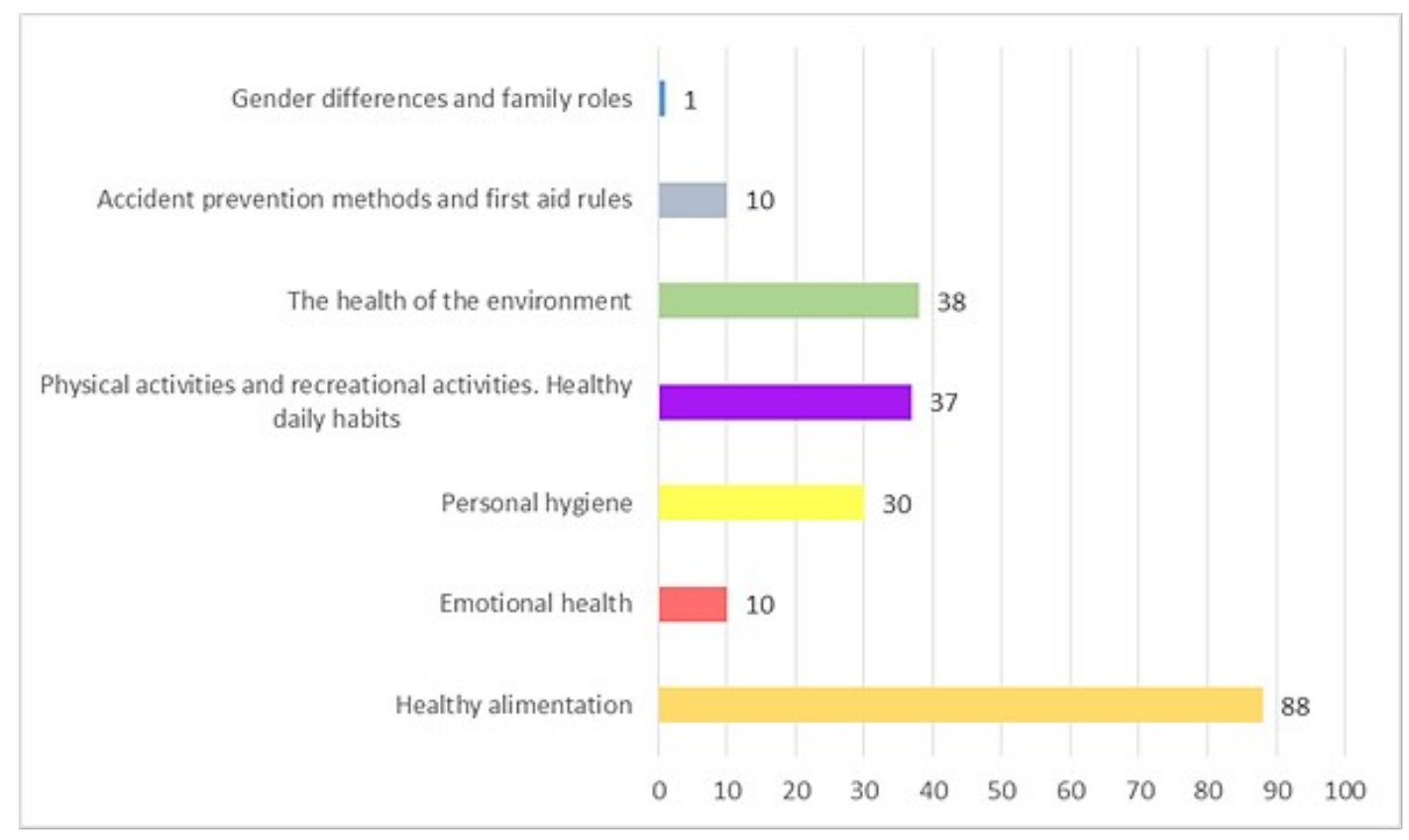

Figure 2. Themes of educational projects implemented in schools and posted on the www.didactic.ro platform

From the analysis of the content of the documents analyzed on various educational platforms or online sites, we reached the following conclusions:

- most educational projects are focused on the healthy eating habits of the pupils;

- a large part of the teachers paid special attention to the protection of the environment, highlighting the impact of these actions on the health of the children;

- most of the projects were carried out by the primary school teachers for a short period (1-5 days), and the rest of the projects were carried out during a semester or even during a school year;

- the main partners of the educational institutions in the implementation of these projects were: town halls, other schools in the country or abroad, County Public Health Departments, NGOs, local medical cabinets (pediatric doctors or dentists).

We believe that effective health education programs have the following characteristics:

- are created in collaboration between educational units, medical personnel (school cabinets, family doctors or pediatricians, hospitals, medical offices, etc.), local authorities and other members of the community;

- contain informative sessions that should be addressed to both students and parents;
- allows pupils to access to accurate information on adopting a healthy lifestyle;

- consist of the active involvement of school counselors and close collaboration with other teachers in the educational unit (for example, biology teachers, physical education teachers);

- they consist of actions in which the health status of the pupils is evaluated and the preventive behaviors are formed;

- the activities are carried out by teachers, who have been trained in advance on how to effectively organize health education activities;

- benefit from good funding and teaching resources (including high-quality didactic materials);

- they are realized in the medium or long term and they approach various topics, with contents adapted to the age and interests of the students.

\section{Discussions}

In March 2020, a legislative proposal was adopted amending and supplementing Law 272/2004 on the protection and promotion of the rights of the child. Thus, the Ministry of Education and the Ministry of Health will implement a strategy on education for health and nutrition, applicable from the 2020-2021 school year (according to the Mediafax press agency). The implementation of at least once a semester of health education programs will 
become compulsory in schools in Romania. The revision of the curriculum of the "health education" discipline is necessary, in the context in which the curricula of the primary education have been modified, and some of them have taken contents associated with this study discipline. Research starting from this topic should be continued, by outlining easy-to-apply and effective health education programs, based on close collaboration with specialized medical personnel. Also, it would be useful to find out what is the percentage of schools in Romania that have decided in the last years to introduce the discipline "Education for health" at the level of primary education, within the Curriculum at the School Decision.

\section{Conclusions}

Health education programs are of particular importance, given that the right to health is a fundamental right of the pupils. They support the adoption of a healthy lifestyle by pupils and their families, contributing to a higher quality of the life of the children and reducing risk behaviors for society. In establishing the strategic directions and decisions regarding how health education programs can be organized and carried out efficiently, should participate decision-makers, children and parents representatives, experts in the area of education and health policy, as well as representatives of civil society which are active in the field of health education.

\section{Acknowledgments}

This work was possible with the financial support of the Operational Programme Human Capital 2014-2020, under the project number POCU 123793 with the title „Researcher, future entrepreneur - New Generation”.

\section{Authors note:}

Diana-Crina Marin is currently a teacher at „Pavel Dan” Theoretical High School, in Câmpia Turzii and postdoctoral researcher at the Babeș-Bolyai University. Her research areas are aimed to find innovative modalities to consolidate the school-family partnership, considering that the school and family should be real partners regarding the children's education. She is also interested in finding the most effective teaching practices that could be successfully used in the educational process.
Musata Bocos is a University Professor and Ph.D. Coordinator at the Faculty of Psychology and Sciences of Education (Babeș-Bolyai University, Cluj-Napoca, Romania). In 1997, she obtained a Ph.D. in Educational Sciences, at the Babeș-Bolyai University. Her research interests are reflected in a series of studies and articles published in important national and international journals. Her teaching activity covers several areas, such as the curriculum theory and methodology, general didactics, and educational research.

\section{References}

Adamowitch, M., Gugglberger, L., \& Dür, W. (2017). Implementation practices in school health promotion: findings from an Austrian multiple-case study. Health Promotion International, 32(2), 218-30.

Dorman, S. (1997). Video and computer games: Effect on children and implications for health education. Journal of School Health, 67(4), 133.

Glanz, K., Rimer, B., \& Lewis, F. (2002). Health behavior and health education. Theory, research and practice. San Francisco, CA: Wiley \& Sons.

Griebler, U., Rojatz, D., Simovska, V., Forster, R. (2014). Effects of student participation in school health promotion: a systematic review. Health Promotion International, 32(2), 195-206.

Inchley, J., Muldoon, J., \& Currie, C. (2006). Becoming a health promoting school: evaluating the process of effective implementation in Scotland. Health Promotion International, 22(1), 65-71.

Lee, A., Lo, A. S. C., Keung, M. V., Kwong, C.M.A., \& Wong, K. K. (2019). Effective health promoting school for better health of children and adolescents: indicators for success, BMC Public Health, 19, 1-12

Lister-Sharp, D., Chapman, S., Stewart-Brown, S., \& Sowden, A. (1993). Health promoting schools and health promotion in schools: two systematic reviews. Health Technology Assessment, 3, 1-201.

Mukoma, W., and Filsher, A.J. (2004). Evaluations of health promoting schools: a review of nine studies. Health Promotion International, 19, 357-368.

Nutbeam, D. (1998). Evaluating health promotion - progress, problems and solutions. Health Promotion International, 13(1), 27-44.

Rowling, L., \& Jeffreys, V. (2006). Capturing complexity: integrating health and education research to inform healthpromoting schools policy and practice. Health Education Research, 21(5), 705-18.

Samdal, O., \& Rowling, L. (2011). Theoretical and empirical base for implementation for health-promoting schools. Health Education, 111(5), 367-90.

Sherman, J., \& Muehlhoff, E. (2007). Developing a Nutrition and Health Education Program for Primary Schools in Zambia. Journal of Nutrition Education and Behavior, 39(6), 335-342.

*** Health 2020. A European policy framework and strategy for the $21 \mathrm{st}$ century. Available at: 
http://www.euro.who.int/_data/assets/pdf_file/0011/199532/Health2020-

Long.pdf?ua $=1$ (accessed at 05.03.2020).

*** The National Program "Health Education in the Romanian School" (Programul Naţional „Educaţia pentru sănătate în şcoala românească”). Available

https://gov.ro/fisiere/programe_fisiere/program-educatie-sanatate.pdf (accessed at 05.03.2020).
*** The National Health Strategy 2014-2020, Health for prosperity (Strategia Naţională de Sănătate 2014-2020, Sănătate pentru prosperitate). Available at: http://www.old2.ms.gov.md/sites/default/files/cadrul_european_de_politici_sa natate_2020.pdf (accessed at 05.03.2020). 